\title{
Understanding New Middle Eastern Leadership: An Operational Code Approach
}

Political Research Quarterly

2018, Vol. 7I(I) 19-3।

(C) 2017 University of Utah

Reprints and permissions:

sagepub.com/journalsPermissions.nav DOI: $10.1177 / 1065912917721744$

journals.sagepub.com/home/prq

(S)AGE

\author{
Özgür Özdamar' and Sercan Canbolat ${ }^{2}$
}

\begin{abstract}
Political Islam and Islamist organizations have broadly gained strength across the Middle East and North Africa (MENA) in the post-Cold War era. Following the Arab uprisings, the Muslim Brotherhood (MB), generally viewed as the world's largest and most influential Islamist organization, has shaped the wider landscape of MENA politics. This study examines MB leadership by comparing M. Morsi of Egypt, R. Ghannouchi of Tunisia, and K. Meshaal of Gaza as examples of Islamist leaders to explain their political belief systems and predict their foreign-policy behavior. We use the operational code approach, a content-analysis software and statistical tests to conduct the study. Results show that the three leaders' foreign policy beliefs are analogous to the averages of world leaders. Results also partially support the hypothesis that their foreign-policy propensities are similar to each other. We conclude that despite the conventional portrayal of MB leadership, these leaders use negotiation and cooperation to settle their differences in foreign affairs, and the best way to approach them is to engage in a Rousseauvian assurance game that emphasizes international social cooperation. Results also suggest important implications in terms of mainstream international relations theories.
\end{abstract}

\section{Keywords}

operational code analysis, leadership, political psychology, foreign policy decision making, the Middle East, Muslim Brotherhood, political Islam, Rachid Ghannouchi, Khaled Meshaal, Mohamed Morsi

\section{Introduction}

The Middle East and North Africa (MENA) is one of the most conflict-prone regions in world politics. The region has experienced a long cycle of political violence, including interstate wars, domestic conflicts, and terrorism, which can be traced back to the demise of the Ottoman Empire and the Western incursion in the wake of World War I. The Arab uprisings that began in Tunisia in December 2010 and spread across the region increased hopes for democratic transition and an open economy. Instead, we have observed Islamist politicians coming to power in relatively free elections and the old establishment's harsh reactions to these electoral victories, followed by civil wars, coups, and third-party interventions. In the rest of the world, governments have struggled to interact with the new regional leadership and have faced criticism for tolerating Islamism as a nondemocratic ideology. For example, former US President Barack Obama was accused of secretly favoring the Muslim Brotherhood (MB), which was labeled as a terrorist organization by the US and Saudi governments as well as by both the Mubarak and Sisi regime in Egypt, and considered to be inimical toward Christianity (Gertz 2015).
We argue that the conviction that MENA states are run by belligerent leaders does not rely on systematic and reproducible data and analysis. We therefore ask the following: Are the political beliefs of the Islamist leaders hostile or cooperative? What are the political instruments they use to achieve their aims - coercion or cooperation? What are their leadership types and strategies-will they bully their opponents or resolve their differences diplomatically? What is the best strategic approach toward these leaders that will result in their cooperation? What is the relevance of such operational code analysis in terms of broader IR theories?

To answer these questions, we focus on political Islam as arguably one of the most powerful forces shaping politics in the region. We assert that one should understand political Islam and its leadership patterns if one needs to conduct business with MENA leaders. Specifically, we

'Bilkent University, Ankara, Turkey

${ }^{2}$ University of Connecticut, Storrs, USA

\section{Corresponding Author:}

Özgür Özdamar, Department of International Relations, Bilkent

University, A Building No: 306, Ankara 06800, Turkey.

Email: ozgur@bilkent.edu.tr 
focus on three regional leaders affiliated with the MB, which holds the distinction of being the largest and most powerful Islamist group operating in the Muslim world (Leiken and Brooke 2007). MB's political beliefs stem from a combination of religious, nationalist, and anticolonial provenances. Despite its significance in MENA and world politics, the MB's political leadership pattern and its foreign policy are understudied within the international relations (IR) discipline. Studies that do analyze the MB lack "realistic empathy," because the field of Middle Eastern studies is fraught with the Western world's political and cultural biases (Karaosmanoglu and Aydinli 2012; White 1991). ${ }^{1}$

This article attempts to help bridge these gaps in the literature by contributing to operational code applications beyond North America (George 1969; Holsti 1977; Leites 1951, 1953; Walker, Schafer, and Young 1998) to the MENA and its typical leaders. As a representative set of Islamist ideology and MB pedigree, we focus on Mohamed Morsi of Egypt, Rachid Ghannouchi of Tunisia, and Khaled Meshaal of Gaza. In the next section, we review operational code analysis, a highly respected leadership assessment method, as a tool for analyzing the political belief systems of this new generation of Islamist leaders. Subsequent sections explain the case selection, research design, and results. The concluding section provides the crux of Islamist foreign policy under the new MENA leaders' stewardship by presenting their general behavioral patterns and the analysis' significance in terms of mainstream IR theories.

\section{Operational Code Analysis: Theory and Hypotheses}

Operational code analysis is a classic leadership assesment approach to foreign policy within the psychological paradigm, focusing on a leader's political belief system or more broadly on a set of beliefs emanating from a society's cultural matrix, which are embedded in a leader's character (Schafer and Walker 2006b; Walker 2000; Walker, Schafer, and Young 1998). Accordingly, political leaders' beliefs are used as causal mechanisms to account for their foreign-policy decisions (George 1969; Schafer and Walker 2006b; Walker 1983). The operational code construct was originally developed by Nathan Leites $(1951,1953)$ as a political strategy to examine the decision-making style of the Soviet Politburo. Leites explained the Soviet Union's precarious relations and uncommon bargaining behavior with US leadership by analyzing Lenin's belief system.

Alexander George (1969) translated Leites' study results into a set of questions whose answers reveal a leader's perceptions about the political universe, the role of the leader in that universe, and various instrumental means for exercising power. George $(1969,1979)$ further elaborated on Leites' study by dividing the questions into two categories: philosophical and instrumental. The first group of questions enables researchers to determine a leader's perceptions of the political universe and the role of the "Other" that the leader confronts. Answers to the second group of questions reveal an image of the leader's "Self" to provide a map of his or her means to achieve foreign-policy goals (George 1979; Walker 1990). Together, the two sets of beliefs account for leaders' tendencies and attitudes toward foreign policy making (Schafer and Walker 2006b).

Building on George's framework, Holsti (1977) constructed an operational code typology. He established six operational codes (A, B, C, D, E, F), which Walker (1983; 1990) later reduced to four groups (A, B, C, DEF). Holsti's typology is based on the nature (temporary or permanent) and the source (individual/society/international system) of conflict in the political world, and it is derived from the leader's master beliefs, which are reflected in the answers to the P-1, I-1, and P-4 questions.

The contemporary operational code analysis uses an automated content-analysis method called the Verbs in Context System (VICS), introduced by Walker, Schafer, and Young (1998). This method retrieves patterns of beliefs from a leader's public statements and then draws inferences about the leader's operational code (Schafer and Walker 2006b; Walker, Schafer, and Young 1998). Schafer and Walker (2006b) further developed preference orderings regarding the outcomes of settlement, deadlock, domination, and submission between Self and Other derived from the indices for their master operational code beliefs (P-1, I-1, P-4) by introducing a Theory of Inferences about Preferences (TIP). It compares the subject's master belief scores (P-1, I-1, and P-4) with the average scores for the 164 speeches uttered by a norming group of thirty-five world political leaders. The comparisons by TIP are utilized to deduce a leader's likely conflict and cooperation strategies (see Table 1).

The signs and indices for all master beliefs enable researchers to observe whether a particular leader's P-1 and I-1 beliefs are below $(<)$ or above $(>)$ the mean score for the norming sample of world leaders. The signs for the P-4a and P-4b indices designate whether these beliefs are more than one standard deviation below $(<)$ or above $(>)$, or whether they are within $(=)$ one standard deviation of the mean for the norming sample. For example, an individual leader with a higher P-4a value than one standard deviation above $(>)$ the mean for the norming group is expected to give more historical control to Self than to Other. If a leader has an average P-4a score located within $(=)$ one standard deviation, he or she gives approximately equal amount of historical control to Self and Other. When the P-4a score of a leader is more than one standard deviation below $(<)$ the mean score for the norming group, it is predicted that such a leader will attribute more 
Table I. An Expanded Theory of Inferences about Preferences.

Self and other values and preference order in a $2 \times 2$ strategic game

Prop. I. If (I-I, P-4a) or (P-I, P-4b) is $(+,<)$, then Settle

$>$ Deadlock $>$ Submit $>$ Dominate (Appeasement)

Prop. 2. If $(\mathrm{I}-\mathrm{I}, \mathrm{P}-4 \mathrm{a})$ or $(\mathrm{P}-\mathrm{I}, \mathrm{P}-4 \mathrm{~b})$ is $(+,=)$, then

Settle $>$ Deadlock $>$ Dominate $>$ Submit (Assurance)

Prop. 3. If $(\mathrm{I}-\mathrm{I}, \mathrm{P}-4 \mathrm{a})$ or $(\mathrm{P}-\mathrm{I}, \mathrm{P}-4 \mathrm{~b})$ is $(+,>)$, then

Settle $>$ Dominate $>$ Deadlock $>$ Submit (Stag Hunt)

Prop. 4. If $(\mathrm{I}-\mathrm{I}, \mathrm{P}-4 \mathrm{a})$ or $(\mathrm{P}-\mathrm{I}, \mathrm{P}-4 \mathrm{~b})$ is $(-,<)$, then

Dominate $>$ Settle $>$ Submit $>$ Deadlock (Chicken)

Prop. 5. If (I-I, P-4a) or (P-I, P-4b) is $(-,=)$, then

Dominate $>$ Settle $>$ Deadlock $>$ Submit (Prisoners' Dilemma)

Prop. 6. If $(\mathrm{I}-\mathrm{I}, \mathrm{P}-4 \mathrm{a})$ or (P-I, P-4b) is $(-,>)$, then

Dominate $>$ Deadlock $>$ Settle $>$ Submit (Bully)

"+"indicates above and "-" indicates below the norming mean. $<,>$, and = indicate below, above, and within the norming average range, respectively, which is $\mathrm{P} 4 \mathrm{a} \pm \mathrm{I} S \mathrm{SD}$. Norming scores for $N=164$ are $\mathrm{P}-\mathrm{I}=+.30, \mathrm{SD}=0.29 ; \mathrm{I}-\mathrm{I}=+.40, \mathrm{SD}=0.43$; and $\mathrm{P}-4=0.22, \mathrm{SD}=$ 0.13 . Norming averages are drawn from Schafer and Walker (2006b), courtesy of Mark Schafer. For another study using the same norming sample, see Malici and Buckner (2008) and Malici (in Walker, Malici, and Schafer 20II).

Source. Schafer and Walker (2006b).

historical control to Other than to Self. Similarly, because the P-4b score is equal to 1 minus (-) the P-4a score, the $\mathrm{P}-4 \mathrm{~b}$ belief's locus of historical control can be calculated accordingly (Schafer and Walker 2006b). The six TIP propositions, as illustrated by Table 1 above, enable researchers to forecast leaders' logical inferences about what is wanted and feasible as a political outcome to attain in foreign-policy statecraft from a strategy of cooperation or conflict, which depends on the sense of historical control attributed to Self (P-4a) and Other (P-4b).

According to Schafer and Walker (2006b), the causal linkage specified by these six propositions is rigorous and fairly consistent with the formal models used in mainstream game theory applications with an emphasis on balance-of-power thinking as a causal mechanism. The rationale behind these propositions also comports with the scientific results of formal modeling simulations of subjective games, in which historical control, tactical intensity, and player perceptions are manipulated (Marfleet and Walker 2006; Snyder and Diesing 1977). We use the three leaders' average scores for their master beliefs regarding Self's preference orderings and their perceived preference orderings of Other regarding the political outcomes of settlement, deadlock, domination, and submission.

\section{Hypotheses}

We formulate two main hypotheses. The first hypothesis focuses on whether the Islamist leaders are significantly different than average world leaders in terms of their foreign policy orientations. The conventional wisdom in the West has largely viewed political Islam as a global security threat, reminiscent of the way that Communism and Soviet Russia were perceived in the course of Cold War. That said, Esposito (2010) argues that even in the case of communist Russia, Western policy makers eventually abandoned a broad-brush and alarmist approach as personified by Senator Joseph McCarty in the 1950s. Yet, many leading Western scholars on MENA and political Islam including Bernard Lewis (2010) have engaged in sheer alarmism and treated Islamist organizations as "benighted peoples," who threaten Western liberal order, and therefore, the Western democracies "either bring those Islamic societies freedom, or they destroy the Western civilization."2

Moreover, Samuel Huntington's (1993) "clash of civilization thesis" echoes a similar conventional portrayal of Islamic societies with political culture and values diverging largely from democratic and liberal systems in the West. Profound cultural divisions, not economic or ideological factors, between the Western and Muslim civilizations are designated as main catalysts pitting one civilization against other, which is destined to be a clash of civilizations in the long run.

Another recurring theme among conventional thoughts on Islamic order is that Islam is a militant religion, which begets radical Islamist groups. Leiken and Brooke (2007) state that MB has been viewed as a "radical Islamist group and as a vital component of the enemy's assault force, which is deeply hostile to the US." B. Rubin (2012) follows suit and describes MB's foreign policy orientation as aggressive and belligerent toward the West. According to B. Rubin $(2012,2)$, "the MB advocates anti-Americanism, violence against the United States as well as terrorism against Israel; that country's extinction; and anti-Semitism, proclaiming that Jews were innately evil and the enemies of Islam."

This article aims to systematically examine these theoretical arguments on political Islam and MB leadership in the light of empirical data from their public statements, which allows researchers to adjudicate whether MB leaders have moderate or radical political beliefs compared with an average leader's beliefs. Therefore, we hypothesize the following:

Hypothesis 1: The operational code beliefs and foreign policy strategies of MB-affiliated MENA leaders are not significantly different (more than one standard deviation) from the beliefs and strategies of the average world leader in the norming group.

The second hypothesis is derived from the operational code analysis literature, which hypothesizes certain political groups have their own political "character" 
that can be measured and used to explain and predict behavior. Nathan Leites (1951) introduced the operational code construct to analyze Soviet leadership. Two years later in a more ambitious analysis, Leites (1953) introduced a sociopsychological account of the historical origins and images of Bolshevism (George 1969). That is, by locating the "Bolshevik character" within Russian history and society, Leites (1953) tells us although every individual is different, they also resemble each other in important respects. This is particularly true if these politicians come from the same historical-sociological background and political ideology. Therefore, A Study of Bolshevism introduces "rules of conduct" and "norms of behavior" for good Bolsheviks to follow.

In psychological terms, "the individual who succeeds in internalizing this preferred character structure thereby accomplishes an 'identity transformation"' (George 1969, 194). If leaders share common historical experiences, then they are likely to have similar operational codes, which express their reactions to these shared experiences. The origins of a leader's operational code beliefs, therefore, are in the historical experiences and cultural norms of the leader's society (Walker 1983). Following the logic of Leites's $(1951,1953)$ analysis of the Bolsheviks, we also subscribe to the view that although each Islamist leader is different, they are similar in important respects due to their political-ideological training that includes a certain interpretation of Middle Eastern history and its political and sociological realities on the ground. As an ego defense mechanism, these reaction formations unconsciously form and appear as similar behavior in daily political affairs. Therefore, we expect Islamist leaders to have similar foreign policy propensities based on similar operational codes, that is, they will have similar operational code types within the Holsti typology of belief systems:

Hypothesis 2: The foreign policy propensities of MB-affiliated MENA leaders, measured by operational code master beliefs, are similar to each other.

\section{Case Selection: Why Political Islamists and the MENA Region?}

We single out the new Middle Eastern leadership affiliated with the MB in the post-Arab uprisings era for several reasons. First, Islamism and Islamist groups have gained strength across MENA in the post-Cold War era (Özdamar 2012, 2017). The MB, as the strongest Islamist ideology in the region, has shaped the wider landscape of MENA politics, especially since the Arab uprisings (Ehrenfeld 2011). Therefore, there is an urgent need to study Islamist MENA leaders' foreign-policy propensities and the approaches they use to realize their political objectives. A scientific study of these leaders may introduce novel theoretical insights into the FPA scholarship and inform policy-oriented scholarship globally.

Second, addressing Malici and Buckner's (2008) scholarly concerns in their study on the beliefs of two socalled MENA "rogue leaders"-Ahmadinejad and alAssad - this study aims to test and perhaps shatter the common beliefs cultivated in the Western world regarding certain political leaders affiliated with the MB. The Malici and Buckner $(2008,783)$ argue,

the conventional wisdom regarding Iran and Syria [and others] is that these are belligerent states headed by hostile leaders. Rarely do policy makers and security analysts make an effort to imagine how international politics are perceived from the Iranian or the Syrian perspectives.

Third, after reviewing recent events in MENA politics, we think that this area provides a very promising research laboratory, in which the study of decision-making processes will be extremely useful. In times of crisis, decisions hinge on "how leaders perceive and interpret the threats based on their belief systems" (Hagan 2001, 11). Similarly, Hermann (1976) argues that the decision-making process becomes paramount in times of foreign-policy crisis, when leaders are forced to make hasty decisions with limited information and in a fog of uncertainty, ${ }^{3}$ which can lead to stress and misperceptions and can greatly influence the dynamics of regional and international politics (Jervis 1976; Janis 1982; Duelfer and Dyson 2011). We find these conditions of uncertainty and crisis to be abundant in the regional politics of the MENA, making it a fruitful arena for operational code studies of political leaders.

\section{Research Design}

This study employs an automated content-analysis program called ProfilerPlus, which codes a leader's use of verbs in speeches via the VICS, which constructs indices to answer George's ten operational code questions and reveal his or her assessment of Self and Other's control over political events in the domain of foreign policy. ${ }^{4}$ Because we analyze the three leaders' public statements by VICS, this research assures strong coding reliability, and the results can be compared with a norming group of world leaders computed by the same software program (Schafer and Walker 2006b). ${ }^{5}$

This study utilizes the three leaders' individual speeches as units of analysis, which allow us to compute means for each leader. To make our content analysis more accessible, we not only specify ranges of transitive verbs coded for the leaders' individual speeches but also present the total of transitive verbs coded for each leader. We used a wide 
collection of their official speeches, press conferences, statements, and book chapters pertaining to foreign-policy issues from late 2011 to mid-2013. To augment our speech sample, we also used public interviews of the three leaders. ${ }^{6}$ Transcripts of the leaders' press conferences and interviews were taken mostly from online documentation platforms such as CNN International, the $\mathrm{BBC}$, and Spiegel. Other scripted texts were accessed from databases including LexisNexis and the Foreign Broadcasting and Information System. ${ }^{7}$ Some public speeches were delivered in English, while others were translated into English by Western institutions or the media.

Our data collection effort follows Walker, Schafer, and Young's $(1998,182)$ speech-selection criteria, which can be summarized as "(1) the subject and object are international in scope, (2) the focus of interaction is a political issue, and (3) the words and deeds are cooperative or conflictual." We also follow Schafer and Walker's (2006a) further criterion that all coded speeches should contain at least fifteen verbs. ${ }^{8}$ Following these criteria, we coded a total of twenty-six texts. Ghannouchi's remarks were taken from interviews, his op-eds, and a book ${ }^{9}$ that includes his comments on foreign affairs. In his seven (relatively long) texts, the minimum number of verbs was sixteen, and the maximum was a hundred, with 464 verbs processed in total. We coded nine texts for Meshaal. The minimum number of verbs was fifty-two, the maximum 179 , and the total 816 .

We found ten suitable texts by Morsi, which include public statements, interviews, and one address to the nation (his Tahrir Square speech). The minimum number of verbs for Morsi was twenty-eight, the maximum 160, and the total 854. In this study, therefore, the total number of verbs coded for all leaders' operational codes is 2,134. Each coded verb was attributed either to the speaker (Self) or other actors (Other) as an exercise of political power and used to construct the VICS indices for the P-1, I-1, and P-4 beliefs in the speaker's operational code.

The study's temporal domain is based on each leader's terms in office. The three leaders' incumbency periods are listed below:

1. Khaled Meshaal: Chief of Hamas Political Bureau (2004-present).

2. Mohammed Morsi: Fifth President of Egypt (June 2012-July 2013).

3. Rachid Ghannouchi: Cofounder and President of the Ennahda Party (October 2011-present).

\section{Results}

The systematic measurement of Morsi, Ghannouchi, and Meshaal's political beliefs yields intriguing results concerning their conceptualizations of foreign policy beliefs and strategies. Table 2 below focuses on the question how the three MB-affiliated leaders compare with an average world leader.

First, regarding the P-1 beliefs, Ghannouchi views the nature of the political realm $(\mathrm{P}-1=0.25)$ as slightly more hostile than the average world leader $(\mathrm{P}-1=0.30)$, whereas Meshaal's perception $(\mathrm{P}-1=0.18)$ is the most conflictual among the group. Morsi perceives the political universe $(\mathrm{P}-1=0.37)$ as friendlier than both of his MB counterparts and the average world leaders $(0.30)$.

Second, there are interesting results concerning the master instrumental belief, the I-1 score. Ghannouchi's tactical orientation is more cooperative $(\mathrm{I}-1=0.57)$ than the average leader's in dealing with foreign-policy problems $(\mathrm{I}-1=0.40)$. Meshaal's score for tactical orientation ( $\mathrm{I}-1=0.41)$ might be surprising, since it is slightly higher than the norming group I-1 score (0.40). Morsi exhibits a more cooperative approach to foreign policy $(\mathrm{I}-1=0.43)$ than both Meshaal and the average world leadership.

The third master belief, P-4, scores reveal that Ghannouchi's sense of control $(\mathrm{P}-4 \mathrm{a}=0.19)$ is slightly lower than the norming sample score (0.22). Meshaal's sense of historical control coincides with the norming group's average P-4a score (0.22). Morsi, however, scores the highest in assuming self-control over political events $(\mathrm{P}-4 \mathrm{a}=0.23)$ among the group. In that sense, all three leaders' average P-4a scores are within one standard deviation $(0.13)$ of the mean for the norming group $(0.22) .{ }^{10}$

Finally, Table 2 also presents statistically significant values for the I-5c - utility of means - and the I- $4 \mathrm{~b}$ importance of timing of actions - beliefs of the studied leaders. First, Ghannouchi and Morsi ascribe significantly higher utility to Appeal and Support tactics (I-5c) when compared with the average leader $(\mathrm{I}-5 \mathrm{c}=0.468, S D=$ $0.229)$. In other words, both MB leaders favor a cooperative strategy as both aimed to avoid further escalation more than average world leadership and, for the most part, considered resources other than military intervention as useful. Meshaal's propensity for Appeal and Support tactics, however, dwells on a close proximity to the average world leadership as his I-5c score (0.41) is within one standard deviation (0.229) of the mean of the reference group.

Second, the I- $4 \mathrm{~b}$ index investigates "the diversity of the leaders' actions in terms of the distribution of words and deeds," and it ranges between 0 and 1 with higher values showing greater flexibility (Schafer and Walker 2006b, 36). Accordingly, only Meshaal's I-4b belief $(0.69)$ is statistically different from those of the average world leader $(0.46, S D=0.31)$ and those of Ghannouchi $(0.26)$ as well as of Morsi (0.54). Such a difference in these leaders' I-4b scores means that Meshaal is more likely to demonstrate greater diversity in his cooperative and conflictual tactics as his instrumental belief system is the most flexible among the comparison group. 
Table 2. The Operational Codes of Ghannouchi, Meshaal, and Morsi Compared with Norming Group Scores.

\begin{tabular}{|c|c|c|c|c|}
\hline & $\begin{array}{c}\text { Norming G. } \\
(n=164)\end{array}$ & $\begin{array}{l}\text { Ghannouchi } \\
\quad(n=7)\end{array}$ & $\begin{array}{c}\text { Meshaal } \\
(n=9)\end{array}$ & $\begin{array}{c}\text { Morsi } \\
(n=10)\end{array}$ \\
\hline \multicolumn{5}{|l|}{ Philosophical beliefs } \\
\hline P-I Nature of political universe (conflict/cooperation) & 0.301 & 0.25 & 0.18 & 0.37 \\
\hline P-2 Realization of political values (pessimism/optimism) & 0.147 & 0.09 & 0.04 & 0.22 \\
\hline P-3 Political future (unpredictable/predictable) & 0.134 & 0.15 & 0.11 & 0.16 \\
\hline P-4 Historical development (low control/high control) & 0.224 & 0.19 & 0.22 & 0.23 \\
\hline P-5 Role of chance (small role/large role) & 0.968 & 0.964 & 0.975 & 0.96 \\
\hline \multicolumn{5}{|l|}{ Instrumental beliefs } \\
\hline I-I Strategic approach to goals (conflict/cooperation) & 0.401 & 0.57 & 0.41 & 0.43 \\
\hline I-2 Intensity of tactics (conflict/cooperation) & 0.178 & 0.20 & 0.22 & 0.25 \\
\hline I-3 Risk orientation (averse/acceptant) & 0.332 & 0.45 & 0.18 & 0.23 \\
\hline \multicolumn{5}{|l|}{ I-4 Timing of action } \\
\hline a. Conflict & 0.503 & 0.43 & 0.59 & 0.57 \\
\hline b. Words/deed & 0.464 & 0.26 & $0.69 *$ & 0.54 \\
\hline \multicolumn{5}{|l|}{ I-5 Utility of means } \\
\hline a. Reward & 0.157 & 0.06 & 0.22 & 0.23 \\
\hline b. Promise & 0.075 & 0.07 & 0.06 & 0.31 \\
\hline c. Appeal/support & 0.468 & $0.65^{*}$ & 0.41 & $0.15^{* *}$ \\
\hline d. Oppose/resist & 0.154 & 0.11 & 0.16 & 0.17 \\
\hline e. Threaten & 0.034 & 0.03 & 0.01 & 0.06 \\
\hline f. Punish & 0.112 & 0.07 & 0.12 & 0.04 \\
\hline
\end{tabular}

Because a difference of means test has been the foundational statistical operation in the leadership assessment research programs to present and simplify the content analysis results, we present the operational code beliefs table with $p$ values to make them as accessible as possible for the readers. Earlier exemplary studies using $p$ values include Schafer and Crichlow (2000), Schafer and Walker (2006a), and Malici and Buckner (2008). Another well-known statistical procedure is presenting the leadership variables with raw scores and then with $z$ values (or scores), yet many operational code scholars are using this procedure to aggregate leaders' belief scores, which is beyond the scope of our study. For example, in his study on German foreign policy and political culture, Malici (2006) utilizes z scores operation solely to present the aggregated operational code scores on the revised Holsti (1977) typology. The mean values for the norming group are $(\mathrm{P}-\mathrm{I}=+.30, S D=0.29 ; \mathrm{I}-\mathrm{I}=+.40, S D=0.43$; $\mathrm{P}-4 \mathrm{a}=.22, S D=0.13 ; \mathrm{I}-5 \mathrm{C}=.46, S D=0.22 ; \mathrm{I}-4 \mathrm{~b}=.46, S D=0.3 \mathrm{I})$. The mean score reflects a sample $(\mathrm{N}=164)$ of public statements by 35 individual state leaders in total from different geographical regions and historical eras (see Malici and Buckner 2008; Schafer and Walker 2006b). Significant differences from norming group are at the following levels (two-tailed test): ${ }^{*} p \leq .02$. ${ }^{* *} p<.001$.

Figure 1 below employs one of the two core systems in world politics, the "world of beliefs," to assess the three MB leaders' political psychology at-a-distance (Walker, Malici, and Schafer 2011, 12). This system defines actors' "state of mind" in the political universe. Walker, Malici, and Schafer $(2011,64)$ argue that leaders' political beliefs are indicative of the ways of exercising rationality and power. Figure 1 can be interpreted from multiple vantage points, yet our heuristic reading of it is as follows: (1) There are two main quadrants in the figure - the upper and lower halves - which correspond to two broad foreign policy strategies, Assurance (upper and always positive half) and Prisoner's Dilemma (lower and generally negative half); (2) the extant mean scores for the world reference group are taken as a benchmark for a comparative analysis of leadership, constituting the origin scores on the coordinate system; (3) each main part has four different quadrants, which zoom in on the disparate variants of the Assurance and Prisoner's Dilemma strategies.

In Figure 1, each individual quadrant carries different theoretical and practical implications concerning the three MB leaders' beliefs and types of leadership styles. The upper half is composed of four micro quadrants, which are different variants of Assurance strategy (in a counter clock-wise direction): (1) Dogmatic Cooperation leadership with a tendency toward Exploitation (DDE) tactics against Other, (2) Pragmatic Cooperation characterized by Deter (DEE) toward Other, (3) Pragmatic Cooperation but with a propensity for Rewarding (DDD) Other, and (4) Erratic Cooperation, which employs a policy of appeasement (DED).

The lower Prisoner's Dilemma zone is also constituted by four different leadership quadrants: (1) Leaders who have propensity for Erratic Conflict strategy and Bluff (EED) tactics, (2) Pragmatic Conflict leaders whose main foreign policy tactic is to Compel (EDD) Other, (3) Pragmatic Conflict leadership characterized by Punish (EEE) tactics, and (4) Dogmatic Conflict leadership style associated with Bully (EDE) tactics. In light of these heuristics, we plot the three MB leaders in Figure 1 to visualize their beliefs and types of leadership styles compared with the norming sample. 


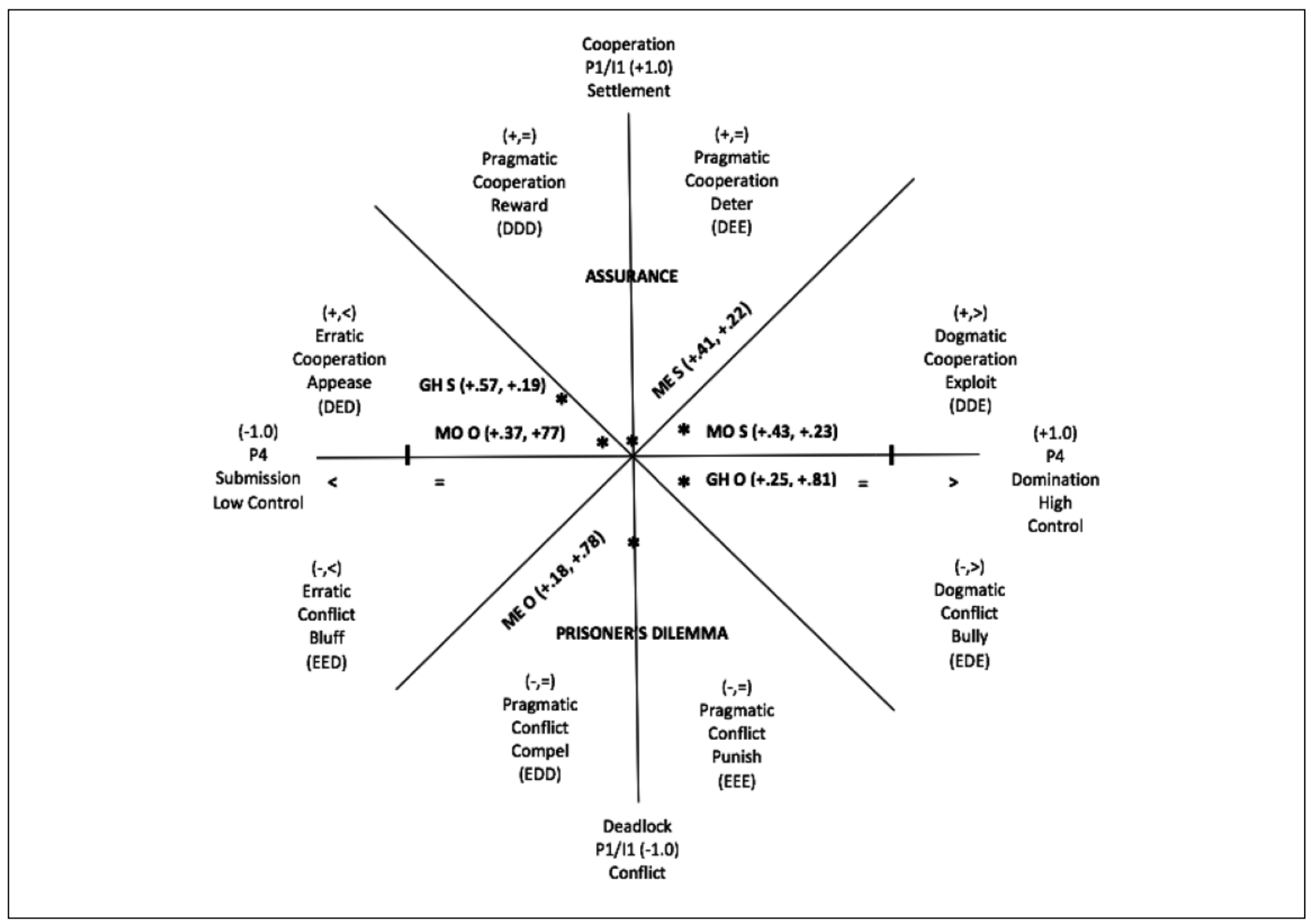

Figure I. Three MB leaders' operational code beliefs and leadership styles compared with average world leader.

The origin of the coordinate system in Figure $\mathrm{I}$ is the reference group scores $(\mathrm{P}-\mathrm{I}=+.30 ; \mathrm{P}-4 \mathrm{~b}=+.78$; I-I $=+.40 ; \mathrm{P}-4 \mathrm{a}=+.22)$. For the sake of simplicity, we used the following abbreviations: $M B=$ Muslim Brotherhood; $G H=$ Ghannouchi; $S=$ Self Image; ME = Meshaal; $M O=M o r s i ; O=$ Image of Other; $\mathrm{DEE}=$ De-escalation, Escalation, Escalation (Deter); DDE = De-escalation, De-escalation, Escalation (Exploit); EDE = Escalation, De-escalation, Escalation (Bully); EEE = Escalation, Escalation, Escalation (Punish); EDD = Escalation, De-escalation, De-escalation (Compel); EED = Escalation, Escalation, De-escalation (Bluff); DED = De-escalation, Escalation, De-escalation (Appease); DDD = De-escalation, De-escalation, De-escalation (Reward).

First, representations of all three leaders' self-images are located on the upper half of Figure 1, signaling that they generally shy away from employing coercive foreign policy tools in favor of a strategy of cooperation. Ghannouchi's I-1 score is the highest (+.57) among the three, while his sense of historical control is the lowest $(\mathrm{P}-4 \mathrm{a}=.19)$. Likewise, Morsi has a cooperative approach to foreign-policy strategy $(\mathrm{I}-1=+.43)$, and his locus of historical control over foreign-policy events $(\mathrm{P}-4 \mathrm{a}=$ $.23)$ is low. Meshaal's self-image is situated in-between the other two leaders. He has the lowest I-1 (+.41) score in his approach to foreign-policy tactics, albeit cooperative, while his sense of self-control over history (P-4a = .22 ) is slightly higher. Thus, Meshaal's self-image falls in close proximity to the other two leaders' in terms of strategic orientation and historical control. Overall, the three leaders share similar beliefs regarding a propensity toward a strategy of cooperation (I-1) constrained by a belief in the low ability to control historical development $(\mathrm{P}-4 \mathrm{a})$ compared with Others in the political universe.

Their images of Other do not resonate similarly across the group. While Ghannouchi and Meshaal have an analogous characterization of Other in the lower half of Figure 1, Morsi's image of Other is located on the upper left side of the figure. This difference is important, as it shows that Ghannouchi and Meshaal believe that the political universe is rather conflictual ( $\mathrm{P}-1)$, and they believe that Other is highly able in exerting control over historical development (P-4). Conversely, Morsi's belief regarding Other $(\mathrm{P}-1)$ shows that the political universe is more peaceful, and he believes that Other's political control over historical events is not extremely high. The average world leader's scores ${ }^{12}$ for the three master beliefs are located at the origin of Figure 1 for comparison with the scores of the three MENA leaders. 
Measuring their proximity to the origin scores, the locations of the three Islamist leaders account for their foreignpolicy preferences. Figure 1 shows that the three leaders' images of Self are similar across the board, falling into the same quadrant. Their images of Other reveal a difference between Morsi and the other two leaders, falling into a different quadrant in Figure 1. These patterns predict similar strategies of cooperation for Self by all three leaders; however, Morsi will expect a different strategy of conflict by Other compared with the other two leaders.

Morsi's Self $(+,=)$ and Other $(+,=)$ scores both correspond to an Assurance Strategy for Self and Other, which signals Morsi's tendency toward a conflict-averse strategy of cooperation within a political environment in which Other mirrors his strategy. The other two leaders, Meshaal and Ghannouchi, also exhibit a foreign policy propensity for a cooperation strategy with Self scores (+, $=)$ located in the Assurance quadrant of Figure 1, but their Other $(-,=)$ scores are located in the Prisoner's Dilemma zone of the figure, which indicate a foreign policy strategy of conflict attributed to Other.

The P-4 scores for each leader are plotted as the distance greater, equal, or lower than the average leader's $\mathrm{P}-4 \mathrm{a}$ of .22 for Self and P-4b of . 78 for Other. There is a uniform pattern among all three leaders' P-4 scores. The sense of control scores for each leader is less than one standard deviation from the average world leader's P-4 scores, so they are similar $(=)$ to the average leader. Therefore, the data partially corroborates Hypothesis 2, since the leaders are alike in their preference rankings for Self, but Morsi differs from the others in preference rankings for Other. All three leaders have similar TIP propensities (Assurance Strategy) for Self, yet Morsi's belief scores exhibit a different TIP strategy attributed to Other (Assurance Strategy) unlike Meshaal and Ghannouchi's (Prisoner's Dilemma). ${ }^{13}$

\section{The Subjective Games of MENA Leaders}

One of the major contributions of the modern operational code literature is its ability to construct individual decision-makers' subjective preference orderings for the political outcomes between Self and Other of settlement, deadlock, domination, or submission and plug them into game theoretic analysis. When we construct strategic interaction games (Brams 1994) for the leaders from their TIP preference orderings in Figure 1, there is a no-conflict game for Morsi, in which both Self and Other rank settlement as the highest outcome. Morsi's conflict-aversion game, in which Self first cooperates and Other reciprocates with the same behavior, is presented below in Table 3. In contrast, the game for Meshaal and Ghannouchi is a mixed-motive game in which Self prioritizes settlement as the highest outcome while Other chooses domination as
Table 3. Subjective Games of the Three MB Leaders.

Mohammed Morsi's No-Conflict Game.

\begin{tabular}{lll}
\hline & $\mathrm{CO}$ & $\mathrm{CF}$ \\
\hline $\mathrm{CO}$ & $\mathbf{4 , 4}$ & $\mathrm{I}, 2$ \\
$\mathrm{CF}$ & 2,1 & 3,3 \\
\hline
\end{tabular}

Khaled Meshaal and Rached Ghannouchi's Mixed-Motive Game.

\begin{tabular}{lll}
\hline & $\mathrm{CO}$ & $\mathrm{CF}$ \\
\hline $\mathrm{CO}$ & $\mathbf{4 , 3}$ & $\mathrm{I}, 4$ \\
$\mathrm{CF}$ & $2, \mathrm{I}$ & 3,2 \\
\hline
\end{tabular}

Self's choices are row and Other's choices are column. Outcomes for Self, Other in each cell are ranked from the highest (4) to the lowest (I) for each player. $\mathrm{MB}=$ Muslim Brotherhood; $\mathrm{CO}=$ Cooperation; $\mathrm{CF}=$ Conflict.

the highest-ranked preference in Table 3. The solution for this game is again settlement, as highlighted in bold.

Confirming Hypothesis 2, the subjective games for all three leaders have settlement as their ultimate solution, which makes them alike in their broad strategic orientation toward Other. However, one significant difference between the three leaders is who moves toward settlement from each cell. In Morsi's game, both Self and Other prefer to "stay" at settlement $(\mathrm{CO}, \mathrm{CO})$ and opt to "move" toward settlement from any other cell as an initial scenario. In Meshaal and Ghannouchi's game, Self chooses to "stay" at settlement $(\mathrm{CO}, \mathrm{CO})$ as an initial state but also to "stay" at deadlock (CF, CF) as an initial state, since preferring "move" to $(\mathrm{CO}, \mathrm{CF})$ culminates in Other choosing to "stay" at $(\mathrm{CO}, \mathrm{CF})$ as a final solution to the game. If Self chooses "stay" at deadlock, however, then Other is supposed to choose "move" to $(\mathrm{CF}, \mathrm{CO})$, because after that Self will choose "move" to $(\mathrm{CO}, \mathrm{CO})$, that is, $(4,3)$, as the final solution for the mixed-motive game.

\section{Discussion}

This section focuses on our last research question: "How do the three MB-affiliated leaders conduct foreign policy? Are their strategic orientations cooperative or conflictual?" We address these questions by comparing the operational code beliefs and subjective games of the three leaders with a narrative of their countries' foreign policy behaviors during their office terms as chief executives.

\section{Ghannouchi: A “Moderate" Islamist's Moderately Complex Foreign Policy}

Rachid Ghannouchi stands out as the most cooperative Brotherhood leader $(\mathrm{I}-1=+.57)$. His recent announcement 
in May 2016 that his Ennahda party will embrace secularism for a more democratic Tunisia and reach out to the opposition reinforces the validity of operational code analysis as an analytical tool. Considering his moderate views on political Islam and his conciliatory approach to power sharing in Tunisian politics, Ghannouchi is acknowledged as a "democrat within Islamism," both in MENA and in Western academic circles (Tamimi 2001). Ghannouchi's thought can be viewed as an amalgamation of Western democratic ideals, Islamic unity, and solidarity objectives, and the idea of historical interconnectedness between Eastern and Western civilizations. Ghannouchi conceives of the possibility of rapprochement between the Muslim world and the West through combining MENA's Islamic thought with the West's ideas of progress and modernity.

Ghannouchi often advocates for countries to have similar economic and political development by creating venues and organizations for Islamic cooperation, similar to Western economic and security platforms such as the European Union. Ghannouchi's perhaps idealistic vision of the Muslim world and the West can be likened to former Turkish PM Necmettin Erbakan's conceptualization of Self and Other in foreign affairs. Erbakan, the "romantic Islamist" of his generation, was one of MENA's leading political Islamists from the 1970s until the early 2000s (Özdamar 2011).

The Tunisian leader possesses the lowest perception among the three leaders of the Self's ability to control historical developments $(\mathrm{P}-4 \mathrm{a}=0.19)$. Ghannouchi's Tunisia pursues a cooperative foreign policy toward his in-group and works to establish good relations with many European countries, despite a relatively conflictual view of Other $(\mathrm{P}-1=+.25)$ compared with the average world leader $(\mathrm{P}-1=+.30)$. Ghannouchi's "moderately moderate" Islamism generates the emergence of a positive-sum mentality in the exercise of political leadership.

\section{Meshaal: One Leader, Multiple Foreign-Policy Behaviors}

Meshaal has the lowest P-1 (+.18) score of the three leaders and is well below the average world leader's score of $(+.30)$ in the norming group. Hamas' hostile relations with Israel and the United States, as well as the organization's outlaw status in the Western world, may have aggravated Meshaal's relatively low level of friendliness toward his out-group. Meshaal's anti-Israeli and anti-US rhetoric may well have driven his P-1 score more downward. Meshaal's I-1(+.41) score is slightly higher than the average world leader but lowest among the three Islamist leaders. His slightly higher I-1 score goes against the conventional wisdom in the United States that the Hamas leader is an uncompromising hardliner. These scores suggest that Meshaal is inclined to pursue cooperative strategies and to eschew the immediate use of military force. His sense of the Self's historical control is equal to the norming group's $(0.22)$. Since his I-1 score is very close to the average world leader's score, it indicates a high propensity to shift quadrants between an Assurance strategy of cooperation and a Prisoner's Dilemma strategy of conflict.

Meshaal's preference ordering is likely to be unstable and, therefore, subject to change depending on the character of the Other, the political context, and the immediacy of the foreign-policy issue. ${ }^{14}$ For example, Meshaal would be expected to subscribe to TIP's Proposition 2, opting for an Assurance Strategy regarding Egypt's Islamist regime, headed by Morsi. However, he might also follow the Prisoners' Dilemma Strategy, specified by Proposition 5 of TIP, toward Netanyahu following the Israeli invasion of Gaza in 2008.

\section{A Neo-Islamist's Conundrum: Morsi's Surprisingly Cooperative Foreign Policy}

Hailing from the hotbed of MB-led political Islam, Morsi is expected to exhibit all the hallmarks of the common ideology characterizing the new leadership in post-2011 MENA. Morsi's Islamist ideology comprises a strong Arab nationalism compounded by anti-imperialist rhetoric, a vision of Muslim solidarity under the banner of MB, and a fierce criticism of Zionism and Israel. Morsi's I-1 (+.43) score in the group is very close to Meshaal's in the domain of foreign policy, which is consistent with his generally critical stance on Israeli and American foreign policy.

Morsi's P-1 $(+.37)$ score is the highest across the group, including the norming sample's $\mathrm{P}-1(+.30)$ score. Having held the top executive office in one of the largest and most powerful nations in MENA and leading the core of the Brotherhood, this experience may contribute to his positive view of the political universe by augmenting his sense of Self's historical control, especially in the post2011 Islamist Egypt. Morsi's P-4a score (0.23) is almost identical to the mean $(\mathrm{P}-4 \mathrm{a}=0.22)$ for the norming group.

Regarding Egyptian-Israeli relations, Morsi demonstrated a full-fledged cooperation, particularly in his position on the Camp David accord, and he favored the tactic of Reward as a part of his Assurance Strategy toward the Israeli state. Although nullifying the treaty would fulfill the MB's old philosophy regarding Zionist Israel, Morsi anticipated the risks of such a radical decision. Above all, by abrogating the treaty, Morsi would jeopardize the national interests of Egypt for the sake of Islamist ideology. Morsi was also preoccupied with internal disturbances and the collapsing Egyptian economy, which threatened the survival of his regime; therefore, it was not a suitable time for a "revolutionary foreign policy." 
Because of the immediacy of Egypt's economic considerations, Morsi strove for a balanced relationship with Israel so as not to antagonize the Western powers. Acknowledging the various risks of breaking the Camp David treaty, Morsi tentatively approved it. This decision can be explained by Morsi's preference ordering for the Self and his perception of Netanyahu's potential strategic interaction. The former suggests that he prioritized a settlement specifically with actors whose perceived control over historical developments was equal to his own sense of control. However, Morsi perceived Netanyahu's preference ordering as Proposition 5, which first favors domination and then, if possible, a cooperative dialogue aiming for a settlement. Because Morsi subscribed to the Assurance Strategy, characterized by Reward and/or Deter tactics, his overall strategy was one of "conditional cooperation."15 If Netanyahu had moved first from an initial state (cell) of deadlock and initiated cooperation with Egypt, therefore, Morsi would have followed suit.

\section{Conclusion}

Operational code analysis and its methodology is one of the strongest political psychology tools available to analyze agents' preferences and the implications of these preferences on foreign policy. Developed in the early 1950s to explain the relationship between psychological traits and foreign-policy action, the approach reveals interesting and counterintuitive results with relevant policy implications. The results show that the most widespread Islamist ideology in the region does not necessarily produce inherently hostile and uncooperative leaders. On the contrary, Ghannouchi, Meshaal, and Morsi appear to have similar philosophical and instrumental beliefs to average world leaders. Also, despite some general patterns such as strong criticism of the United States and Israel, and their relatively low P-4a scores, these leaders do not speak with one voice in their tactical intensity, and their foreign-policy behaviors are not always harmonious.

Perhaps the most controversial and important conclusion of this article is that if offered opportunities, all three leaders are expected to exhibit cooperative behavior, albeit in varying degrees from being somewhat cooperative (Meshaal and Morsi) to being definitely cooperative (Ghannouchi). More generally, recent studies on regional leadership (Kesgin 2013; Malici 2007; Malici and Buckner 2008) collectively show that many leaders in the Middle East are not inherently hostile, uncooperative, irrational, or "rogue." On the contrary, their political beliefs are associated with cooperative strategies and rational policy behaviors very similar to the average world leader. The policy implications originating from such firm conclusions may lead to revolutionary approaches to foreign policy decisions vis-à-vis Islamist leaders by foreign governments.
Put simply, these results suggest engaging in positive, diplomatic relations with these leaders by providing conciliatory opportunities. When given an opportunity and confidence, these leaders are very likely to pursue shared interests, negotiate constructively, give concessions if necessary, and avoid the use of force. This possibility has many implications for conflict resolution and peacemaking in the region. Akin to the P5+1 approach to the Iranian nuclear program, such a tact can help solve many problems in the region. For example, instead of isolating Hamas, Israeli policy makers should find creative ways to restart the relations and provide confidence measures to the Hamas' chiefs. Similarly, Western leadership should recognize that outlawing the MB in Egypt and executing Mohammad Morsi would only exacerbate the nascent democratization process in the country. Tunisia's march toward democracy should be coupled with strengthened relations with Europe to accelerate positive transformation.

Besides the implications detailed above, we also believe that an operational code analysis of MENA leaders can contribute to the advance of mainstream IR theories in that it helps explain the operation of individual-level mechanisms, such as "strategic culture," as frequently discussed in the realist IR literature. We subscribe to the position that the cognitivist research school can strengthen structural realist accounts by bringing leadership explicitly back into the analysis of IR (Hagan 2001; Schafer and Walker 2006b). The operational code's master beliefs are particularly appropriate focal points to enrich realist analyses of conflict, as they identify beliefs about the nature of the environment (P-1) as friendly or threatening, strategies of appeasement or balancing (I-1), and the balance of power (P-4) between states.

More generally, the master beliefs in operational code analysis (P-1, I-1, and P-4) are particularly illuminating in terms of major debates in IR theory, such as the realistidealist (liberal) dichotomy (Walker and Schafer 2007). Specifically, we maintain that our results help us assess the extent to which realism and liberalism's main assumptions regarding cooperation, conflict, and control are embedded in the belief systems of Morsi, Meshaal, and Ghannouchi. Although we do not aim to test the main hypotheses of realism and liberalism in this article, we do argue that our results are compelling and relevant in terms of broader IR theory discussions about whether and when leaders are optimistic and oriented toward cooperation (as liberals contend) or are pessimistic and oriented toward a conflictual view of the political universe (as realists assume).

The realist approach to international politics generally assumes the political world is one of conflict and selfhelp. Scholars ranging from the ancient Greek historian Thucydides to the most recent examples focusing on US grand strategy (Mearsheimer and Walt 2016) suggest that, at the minimum, states aim to survive in an anarchical 
system in which conflict is prevalent. In operational code analysis, this point of view is represented in the lower two quadrants of the operational code typology and the corresponding DEF and B types of leadership, which maintain a negative image of Other. Agents, especially those operating in more conflictual regions, are expected to have an image of Other located in these lower quadrants.

Therefore, political realism's expectation concerning the MB leadership's philosophical beliefs would reflect a hostile image of the political universe. Meshaal and Ghannouchi seem to partially confirm this expectation. Their worldview is relatively conflictual. They expect the political Other to use tactics of bullying and punishment in international affairs. The anomalous result is former Egyptian President Morsi's rather high P-1 scores and a positive image of Other. We suspect that Morsi's background and rather short tenure in office is the main reason for this score. Previous studies prove that beliefs are not static (Schafer and Walker 2006b; Walker, Schafer, and Young 1998). Leaders' beliefs can and do change over time, especially after spending a certain time in office, for example, after completing a first term. Morsi's rather positive image of Other may have to do with his short period in office and the limited time he spent dealing with external opposition and great powers.

The liberal school in IR is associated with the idealist strategic culture that emphasizes cooperation in international affairs. The liberal school's roots are attributed to Immanuel Kant's liberal peace argument (Bull 1977; Keohane 1986). Liberal theorists of IR would expect that the MB leadership's instrumental beliefs would reflect a propensity to employ diplomatic means and a reluctance to employ force in international affairs. In other words, liberal theory emphasizes cooperative relations between states represented by higher I- 1 scores in the operational code construct. The upper two quadrants and leadership types $\mathrm{A}$ and $\mathrm{C}$ in operational code analysis correspond to liberal theory's expectations of national leaders' beliefs about foreign policy cooperation.

In our analysis, all three MB leaders have cooperative self-images corresponding to upper quadrant locations, which is interesting given the hostile environment in which they operate. This result may open further debate as to whether states balance in hostile environments, as predicted by realists, while they appease in friendly environments, as predicted by liberals. Neither theory addresses particularly well the possibilities of friendly behavior in hostile environments and hostile behavior in friendly environments. The three leaders present a rather mixed picture due to their low (Ghannouchi), average (Meshal), and high (Morsi) sense of historical control measured by P-4a in operational code construct. The leaders' beliefs about the balance of power, the balance of threat, and strategies of cooperation and conflict indicate that they may constitute important intervening variables between environment and behavior in both realist and liberal accounts of world politics.

In conclusion, the results in this paper and the discussion of their contribution to IR theory fits into a broader debate within the IR literature, which suggests there is an

emerging consensus among constructivists, political psychologists, neoclassical realists, and institutionalists, namely, that neorealist and neoliberal structural theories are underspecified without including agent-oriented models of beliefs to capture the microfoundations of strategic interactions between states . . . A "theory complex," created by an agent-centered analysis of beliefs plus a structural analysis of contexts, provides the best model ... . (Walker and Schafer 2007, 771)

\section{Acknowledgments}

The authors wish to acknowledge the helpful comments of Stephen Walker, Akan Malici, Zaid Eyadat, and the journal's anonymous reviewers. The data used in this article can be found at http://ozgur.bilkent.edu.tr/research.html.

\section{Declaration of Conflicting Interests}

The author(s) declared no potential conflicts of interest with respect to the research, authorship, and/or publication of this article.

\section{Funding}

The author(s) received no financial support for the research, authorship, and/or publication of this article.

\section{Notes}

1. There are a few exceptions to the Western focus of the literature. For example, Malici and Buckner (2008) focus on leadership in Syria and Iran and conclude that these leaders' strategic orientation is not as hostile as it is perceived in the Western academia. The two leaders Malici and Buckner analyze subscribe to a Shia understanding of Islam, and also Syria's al-Asad is considered to be a secularist. Kesgin (2013) profiles Turkey's Islamist Prime Ministers in the post-Cold War era and compares them with the secular Turkish prime ministers. Yet, Kesgin (2013) focuses exclusively on the puzzle regarding the "seculars vs. Islamists" schism in Turkey rather than on transnational political Islam and religious organizations, for example, Muslim Brotherhood in MENA region.

2. These quotations were adopted from a lecture delivered by Bernard Lewis on July 16, 2006. Available at http://www. realclearpolitics.com/articles/2006/09/bring_them_freedom_or_they_des.html (Accessed 07.05.2016).

3. Our study concurs with Deutsch and Merritt $(1965,145)$, Jervis (1976, 118), and Walker, Malici, and Schafer (2011) on "relative stability of core beliefs over time" as a result of the strong tendency for people to assimilate new information in a fashion that conforms to their pre-existing beliefs. 
4. ProfilerPlus version 5.8.4 and the VICS indices for operational code scores were courteously provided by Michael Young of Social Science Automation, Inc. We also thank Moynihan Institute fellow Hanneke Derksen for providing ProfilerPlus and the coding package. A trial version of ProfilerPlus 5.8.4. can be downloaded from http://www. socialscience.net (last access: 10.10.2016).

5. Unlike the leadership trait analysis (LTA), the operational code research program does not have regional norming samples. Thus, this article compares the MB leaders only to the world leader reference group.

6. There is no scholarly consensus among the proponents of FPA concerning the canonical type and content of speeches being used for leadership profiling; some scholars warn against using spontaneous speeches, that is, interviews (see Dille 2000; Renshon 2009), while others do not limit the universe of eligible speeches to be used in leadership assessment research programs (see Hermann 2005; Schafer 2000). We followed the latter suggestion in this research to overcome a potential dearth of speeches by MB leaders.

7. Speeches collected for this research are listed in the supplemental material.

8. In profiling the MB's political leadership, we did not develop distinct dictionaries for further specifying each leader's Self and Other attributions because the coded speeches were international in scope, which reflect the basic grammar and stylistic rules of English with clear distinction between the "Self" and "Other." Besides, we argue that developing distinct and very specific "Self vs. Other" dictionaries for non-English-speaking leaders risks the "external validity" of leadership research as the established common dictionary renders the leadership analysis results comparable with the averages of world leadership reference group.

9. Tamimi (2001). Ghannouchi's speeches are drawn mostly from Chapter 6 of the book titled "The Territorial State and the New World Order."

10. Because this section compares the three MENA leaders' belief systems with the average world leader, it focuses exclusively on whether there are statistically important differences between the MENA leaders (individually and as a group) and the norming group. For more information on this statistical application, see Malici and Buckner (2008, 796) and Achen (1982).

11. According to Walker, Malici, and Schafer $(2011,65)$, the two systems, the "world of beliefs" and "world of events" constitute the micro-politics of foreign policy decisionmaking and the behavioral model of international relations (also known as the "two worlds of interaction"). Figure 1 captures the three MB leaders' worlds of beliefs through the TIP (Schafer and Walker 2006b), whereas Table 3 presents their worlds of events by using Steven Brams's (1994) TOM.

12. For the major operational code works using the same data on all the average leader's belief scores including both the mean scores and standard deviations, see Schafer and Walker (2006a), Schafer and Walker (2006b), Walker and Schafer (2007), and Malici and Buckner (2008).
13. Leadership types and strategies associated with them are measured by P1, I1, and P4 scores. In terms of P4, there is a uniform pattern among all three leaders. In terms of I1, all three leaders have the same TIP preference orderings (Assurance Strategy) for Self. In terms of Other (P1), Morsi's scores for Other show a different TIP preference for Other (Prisoner's Dilemma) than the other two leaders'. In other words, Hypothesis 2 is confirmed in eight out of nine comparisons. Therefore, we conclude the data partially corroborates Hypothesis 2 .

14. There is a scholarly debate about whether decision makers have a general and consistent operational code or whether there are different operational codes for the different issues they face in the foreign-policy domain (Walker, Schafer, and Young 1998). Although we are well aware of this debate within the operational code research program and our position generally comports with the latter argument, our study of the MB-affiliated leaders does not dissect these leaders' foreign policy profiles into different issue areas as it is not the primary focus of this research.

15. The term "strategy of conditional cooperation" is borrowed from Malici and Buckner's $(2008,797)$ study where the term is used to explain an Assurance strategy.

\section{Supplemental Material}

Online appendix materials for this article are available with the manuscript on the Political Research Quarterly (PRQ) website.

\section{References}

Achen, Christopher. 1982. Interpreting and Using Regression. Newbury Park: SAGE.

Brams, Steven. 1994. Theory of Moves. Cambridge: Cambridge University Press.

Bull, Hedley. 1977. The Anarchical Society: A Study of Order in World Politics. London: Macmillan.

Deutsch, Karl W., and Richard L. Merritt. 1965. "Effects of Events on National and International images." In International Behavior: A Social-Psychological Analysis, edited by H. C. Kelman, 130-87. New York: Holt, Rinehart \& Winston.

Dille, Brian. 2000. "The Prepared and Spontaneous Remarks of Presidents Reagan and Bush: A Validity Comparison for At-a-Distance Measurements." Political Psychology 21 (3): 573-85.

Duelfer, A. Charles, and Stephen B. Dyson. 2011. "Chronic Misperception and International Conflict: The US-Iraq Experience." International Security 36 (1): 73-100.

Ehrenfeld, Rachel. 2011. "The Muslim Brotherhood Evolution: An Overview." American Foreign Policy Interests 33 (2): 69-85.

Esposito, L. John. 2010. "It's the Policy, Stupid: Political Islam and US Foreign Policy." Harvard Business Review. http:// hir.harvard.edu/articles/1543.

George, Alexander. 1969. "The 'Operational Code': A Neglected Approach to the Study of Political Leaders and Decision Making." International Studies Quarterly 23:190-222. 
George, Alexander. 1979. "The Causal Nexus between Beliefs and Behavior: The "Operational Code" Belief System." In Psychological Models in International Politics, edited by L. Falkowski, 95-124. Boulder: Westview Press.

Gertz, Bill. 2015. "Obama Secretly Backing the Muslim Brotherhood." The Washington Times. http://www.washingtontimes.com/news/2015/jun/3/inside-the-ring-muslim-brotherhood-has-obamas-secr/?page=all (accessed July 7, 2017).

Hagan, D. Joe. 2001. "Does Decision Making Matter? Systemic Assumptions versus Historical Reality." International Studies Review 3 (2): 5-46.

Hermann, G. Margaret. 1976. "Circumstances under Which Leader Personality Will Affect Foreign Policy: Some Propositions." In In Search of Global Patterns, edited by J. Rosenau. New York: Free Press.

Hermann, G. Margaret. 2005. “Assessing Leadership Style: Trait Analysis." In The Psychological Assessment of Political Leaders: With Profiles of Saddam Hussein and Bill Clinton, edited by J. Post, 178-214. Ann Arbor: The University of Michigan Press.

Holsti, R. Ole. 1977. The "Operational Code" as an Approach to the Analysis of Belief Systems. Durham: Duke University Press.

Huntington, P. Samuel. 1993. "The Clash of Civilizations and the Remaking of World Order." Foreign Affairs 72 (3): 22-49.

Janis, L. Irving. 1982. Victims of Groupthink. Boston: Houghton Mifflin.

Jervis, Robert. 1976. Perception and Misperception in International Politics. Princeton: Princeton University Press.

Karaosmanoglu, Ali, and Ersel Aydinli. 2012. "Launching All Azimuth." All Azimuth 1 (1): 5-7.

Keohane, O. Robert. 1986. Neorealism and Its Critics. New York: Columbia University Press.

Kesgin, Baris. 2013. "Leadership Traits of Turkey's Islamist and Secular Prime Ministers." Turkish Studies 14 (1): 136-57.

Leiken, Robert, and Steven Brooke. 2007. "Moderate Muslim Brotherhood." Foreign Affairs 86 (2): 107-21.

Leites, Nathan. 1951. The Operational Code of the Politburo. New York: McGraw-Hill.

Leites, Nathan. 1953. A Study of Bolshevism. New York: Free Press.

Lewis, Bernard. 2010. Faith and Power: Religion and Politics in the Middle East. London: Oxford University Press.

Malici, Akan. 2006. "Germans as Venutians: The Culture of German Foreign Policy Behavior." Foreign Policy Analysis 2 (1): 37-62.

Malici, Akan. 2007. "Thinking about Rogue Leaders: Really Hostile or Just Frustrated?" The Whitehead Journal of Diplomacy and International Relations 8 (2): 103-11.

Malici, Akan, and Allison, L. Buckner. 2008. "Empathizing with Rogue Leaders: Mahmoud Ahmadinejad and Bashar al-Asad." Journal of Peace Research 45 (6): 783-800.

Marfleet, G., and Stephen G. Walker. 2006. "A World of Beliefs: Modeling Interactions among Agents with Different Operational Codes." In Beliefs and Leadership in World Politics, edited by M. Schafer and S. Walker, 53-76. New York: Palgrave Macmillan.
Mearsheimer, J. John, and Stephen M. Walt. 2016. "The Case for Offshore Balancing: The Superior US Grand Strategy." Foreign Affairs, July/August, 70-83.

Özdamar, Ozgur. 2011. "Foreign Policy Belief Systems of Political Islamists: An Operational Code Approach.” Paper presented in Annual Meetings of ISA 2011, Montreal, March 16-19.

Özdamar, Ozgur. 2012. "Neo-Islamists' Operational Code: Old Philosophy, New Tactics?" Paper presented in Annual Meetings of ISA 2012, San Francisco, April 1-4.

Özdamar, Ozgur. 2017. "Leadership Analysis at a 'Great Distance': Using Operational Code Construct to Analyze Islamist Leaders." Global Society 31 (2): 167-98.

Renshon, Jonathan. 2009. "When Public Statements Reveal Private Beliefs: Assessing Operational Codes at a Distance." Political Psychology 30 (4): 649-61.

Rubin, Barry. 2012. "Understanding Muslim Brotherhood." Policy Brief. Foreign Policy Research Institute. http:// www.fpri.org/article/2012/07/understanding-the-muslimbrotherhood/ (accessed May 6, 2016).

Schafer, Mark. 2000. "Issues in Assessing Psychological Characteristics at a Distance." Political Psychology 21 (3): 511-27.

Schafer, Mark, and Scott Crichlow. 2000. "Bill Clinton's Operational Code as Measured by Spontaneous and Prepared Remarks.” Political Psychology 21 (3): 559-71.

Schafer, Mark, and Stephen G. Walker. 2006a. "Democratic Leaders and the Democratic Peace: The Operational Codes of Tony Blair and Bill Clinton." International Studies Quarterly 50 (3): 561-83.

Schafer, Mark, and Stephen G. Walker. 2006b. "Operational Code Analysis at a Distance." In Beliefs and Leadership in World Politics, edited by Mark Schafer and Stephen G. Walker, 562-64. New York: Palgrave Macmillan.

Snyder, Glenn, and Paul Diesing. 1977. Conflict among Nations. Princeton: Princeton University Press.

Tamimi, S. Azzam. 2001. Rachid Ghannouchi: A Democrat within Islamism. New York: Oxford University Press.

Walker, G. Stephen. 1983. "The Motivational Foundations of Political Belief Systems: A Re-Analysis of the Operational Code Construct." International Studies Quarterly 27:179201.

Walker, G. Stephen. 1990. "The Evolution of Operational Code Analysis.” Political Psychology 11 (2): 403-18.

Walker, G. Stephen. 2000. Forecasting the Political Behavior of Leaders with the Verbs in Context System of Operational Code Analysis. Hilliard: Social Science Automation.

Walker, G. Stephen, Akan Malici, and Mark Schafer. 2011. Rethinking Foreign Policy Analysis: States, Leaders, and the Microfoundations of Behavioral International Relations. New York: Routledge.

Walker, G. Stephen, and Mark Schafer. 2007. Theodore Roosevelt and Woodrow Wilson as Cultural Icons of US Foreign Policy. Political Psychology 28:747-76.

Walker, G. Stephen, Mark Schafer, and Michael D. Young. 1998. "Systematic Procedures for Operational Code Analysis: Measuring and Modeling Jimmy Carter's Operational Code." International Studies Quarterly 42 (1): 175-90.

White, Ralph. 1991. "Empathizing with Saddam Hussein." Political Psychology 12 (2): 291-308. 